\title{
ETHzürich
}

ETH Library

\section{Comparison of bending stiffness of cross-laminated solid timber derived by modal analysis of full panels and by bending tests of strip-shaped specimens}

\author{
Journal Article \\ Author(s): \\ Steiger, René; Gülzow, Arne; Czaderski, Christoph; Howald, Martin T.; Niemz, Peter \\ Publication date: \\ 2012-01 \\ Permanent link: \\ https://doi.org/10.3929/ethz-b-000041494
}

Rights / license:

In Copyright - Non-Commercial Use Permitted

Originally published in:

European Journal of Wood and Wood Products 70(1-3), https://doi.org/10.1007/s00107-011-0521-7 


\title{
Comparison of bending stiffness of cross-laminated solid timber derived by modal analysis of full panels and by bending tests of strip-shaped specimens
}

\author{
René Steiger • Arne Gülzow • Christoph Czaderski • \\ Martin T. Howald • Peter Niemz
}

Received: 30 April 2010 / Published online: 2 February 2011

(C) Springer-Verlag 2011

\begin{abstract}
The design of cross-laminated solid timber (CLT) as load-bearing plates is mainly governed by serviceability criterions like maximal deflection and susceptibility to vibration. Hence, predicting the respective behavior of such plates requires accurate information about their elastic properties. According to product standards, the bending stiffness of CLT has to be assessed from 4-point bending tests of strip-shaped specimens, cut from the CLT panels. By comparing elastic properties of CLT derived by means of modal analysis of full panels with the results of bending tests on $100 \mathrm{~mm}$ and $300 \mathrm{~mm}$ wide strip-shaped specimens it is shown, that by testing single $100 \mathrm{~mm}$ wide strip-shaped specimens bending stiffness of full panels cannot be assessed correctly, whereas single $300 \mathrm{~mm}$ wide strips or averages of 5 to $6100 \mathrm{~mm}$ wide strip-shaped specimens lead
\end{abstract}

\section{R. Steiger $(\bowtie)$}

Wood Laboratory, Empa, Swiss Federal Laboratories for Materials Science and Technology, Ueberlandstrasse 129, 8600 Dübendorf, Switzerland

e-mail: rene.steiger@empa.ch

A. Gülzow

Carbo-Link GmbH, Undermühlistrasse 26, 8320 Fehraltorf, Switzerland

C. Czaderski

Structural Engineering Research Laboratory, Empa, Swiss Federal Laboratories for Materials Science and Technology, Ueberlandstrasse 129, 8600 Dübendorf, Switzerland

M.T. Howald

Kronospan Schweiz AG, Willisauerstrasse 37, 6122 Menznau, Switzerland

P. Niemz

Institute for Building Materials, Wood Physics, ETH, Swiss Federal Institute of Technology Zurich, Schafmattstrasse 6, 8093 Zürich, Switzerland to acceptable results. Hence, strip-shaped specimens should only be used in the course of factory quality control or when assessing the bending stiffness of parts of CLT panels used as beam-like load-bearing elements but not to derive bending stiffness of gross CLT panels. Verification by carrying out static bending tests of gross CLT panels under different loading situations showed that alternatively to tests on strip-shaped specimens or estimations with the compound theory, the overall stiffness properties of CLT can be derived directly by a modal analysis of full-size panels.

\section{Vergleich der Biegesteifigkeit von Brettsperrholz ermittelt mittels Modalanalyse von Platten und mittels Biegeversuchen an Plattenstreifen}

Zusammenfassung Maßgebend in der Bemessung von Brettsperrholz (BSP) als lasttragende Platte ist meistens der Nachweis der Gebrauchstauglichkeit, d. h. die Einhaltung von Anforderungen an die Durchbiegung oder an die Schwingungsempfindlichkeit. Demzufolge müssen die Steifigkeiten der Platten in den Haupttragrichtungen bekannt sein. Gemäß den einschlägigen Normen ist die Biegesteifigkeit von BSP anhand von 4-Punkt-Biegeversuchen an Streifen $\mathrm{zu}$ bestimmen, welche man von den Platten abtrennt. Ein Vergleich von Plattensteifigkeiten von BSP bestimmt mittels Modalanalyse an ganzen Platten mit Resultaten aus Biegeversuchen an 100 mm bzw. 300 mm breiten Plattenstreifen zeigt, daß auf Basis von Versuchen an einzelnen $100 \mathrm{~mm}$ breiten Plattenstreifen die Steifigkeitseigenschaften von BSP-Platten nicht zuverlässig bestimmt werden können. Jedoch führen Versuche an einzelnen $300 \mathrm{~mm}$ breiten Streifen oder die Mittelwertbildung an Stichproben von 5 bis $6100 \mathrm{~mm}$ breiten Streifen zu brauchbaren Resultaten. Versuche an Plattenstreifen sollten also nur im Rahmen der 
Produktionskontrolle oder zur Ermittlung der Steifigkeit von als Biegebalken eingesetzten BSP-Streifen angewendet werden, nicht aber zur Ermittlung der Biegesteifigkeit von BSPPlatten. Mittels statischer Prüfbelastung an ganzen Platten konnte des Weiteren gezeigt werden, daß die Steifigkeitseigenschaften von BSP-Platten als Alternative zu Versuchen an Plattenstreifen und zu Berechnungen nach der Verbundtheorie auch mittels Modalanalyse bestimmt werden können.

\section{Introduction}

\subsection{The engineered wood product CLT}

Cross-laminated solid timber (CLT) (Fig. 1) is a panelshaped engineered wood product (EWP), assembled of cross-wise oriented layers of lamellas (mostly softwood) which, compared to the raw material, benefits from homogenized mechanical properties. In contrast to other panelshaped EWP, CLT is not only used as component of structural elements, but rather for load bearing plates and shear walls itself. As for other load bearing structural elements, the design of CLT requires verification of sufficient strength and serviceability. Since in practice the design of plates loaded perpendicular to the plane is often governed by serviceability criterions like maximal deflection and susceptibility to vibration, predicting the adequate behavior of such panels has to be based on accurate information about their elastic properties.

\subsection{Bending stiffness properties of CLT}

Stiffness properties of CLT panels parallel and perpendicular to the grain direction of the face layers are usually derived on the basis of mechanical properties of the raw material (layers) using the compound theory (Blass and Görlacher 2003; Bodig and Jayne 1993) or other verification methods like Ren plate theory (Ren 1986), Reddy plate theory (Reddy 1984), Timoshenko theory for beams or plates (Altenbach et al. 1996), shear analogy method by Kreuzinger (1999), Gamma method (CEN 2004b). Stiffness properties of CLT can also be assessed by non-destructive testing of gross panels, e.g. by a combination of theoretical and experimental modal analysis (Gsell et al. 2007) as will be explained in more detail in the methods part. Performing bending tests of strip-shaped specimens cut from gross panels is another way of evaluating stiffness properties of CLT. Such tests suffer from being tedious and are not in all cases a reliable indicator of the CLT's real mechanical performance (Czaderski et al. 2007; Jöbstl et al. 2006). However, with respect to building practice, strip-shaped specimens have certain legitimacy, since in real buildings

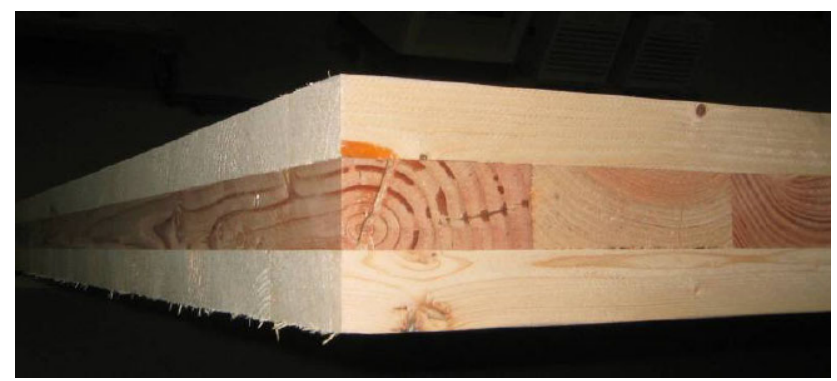

Fig. 1 Cross-sectional view of a cross-laminated solid wood panel (CLT) with 3 layers

Abb. 1 Schnittbild einer 3-lagigen Brettsperrholzplatte (BSP)

small strips quite frequently occur, e.g. close to stairway holes in floors or as beams above window or door openings.

\subsection{Normative regulations on testing and sampling}

Up to now CLT is mainly produced and applied in Europe. European regulations regarding the derivation of performance characteristics, evaluation of conformity and (CE-) marking of wood-based panels for use in constructions are given in EN 13986 (CEN 2004c). In this standard CLT is called "Solid Wood Panel" (SWP). SWP are either onelayer panels or consist of two outer layers with grain direction running parallel and at least one inner layer with its grain direction at $90^{\circ}$ to the outer layers (CEN 2001). With regard to deriving bending stiffness of SWP, in EN 13986 reference is made to the standard EN 789 (CEN 2004a), which asks for 4-point bending tests of strip-shaped specimens with a width of $300 \pm 5 \mathrm{~mm}$, cut from the SWP. The span has to be taken as $300 \mathrm{~mm}+32 \cdot h$, $h$ being the nominal thickness of the SWP. These dimensions however, are not common when testing bending members for structural applications, where usually procedures and specifications of EN 408 (CEN 2003b) are followed. Due to different geometrical properties of the raw material, production methods and application in practice, CLT is not fully equal to SWP, which is not taken into account by to date's product standards. That is why when testing CLT, not EN 789 specifications should be followed but rather those of EN 408. However, up to now testing of CLT is not explicitly mentioned in EN 408. Nevertheless EN 408 specifications and procedures were applied in this study.

Apart from EN 13986, a CE-marking of CLT is also possible on the basis of European Technical Approvals (ETA). These approvals are issued based on a Common Understanding of Assessment Procedure (CUAP) where also bending tests similar to the EN 408 procedures are required.

According to EN 789 sampling has to guarantee adequate consideration of variability within the production of 
Table 1 Geometrical properties and sample sizes of the investigated CLT panels

Tab. 1 Geometrische Abmessungen und Stichprobenumfang der geprüften Brettsperrholzplatten

\begin{tabular}{|c|c|c|c|c|}
\hline Series & Length $^{\mathrm{a}} \times$ width $[\mathrm{m}]$ & Thickness $h[\mathrm{~mm}]$ & Lay-up $[\mathrm{mm}]$ & Number of tested panels \\
\hline \multirow[t]{2}{*}{1} & $2.50 \times 2.50$ & 70 & Product A and B: 10/50/10 & 9 of each product \\
\hline & & & Product A and B: 25/20/25 & 3 of each product \\
\hline \multirow[t]{6}{*}{2} & $2.50 \times 2.50$ & 110 & Product A: $35 / 40 / 35$ & 3 \\
\hline & & & Product B: 20/70/20 & 3 \\
\hline & $4.00 \times 2.50$ & 80 & Product A: $25 / 30 / 25$ & 3 \\
\hline & & & Product B: $15 / 50 / 15$ & 3 \\
\hline & & 110 & Product A: $15 / 15 / 20 / 15 / 15$ & 3 \\
\hline & & & Product B: 35/40/35 & 3 \\
\hline
\end{tabular}

${ }^{\text {a }}$ Direction parallel to the grain of the face layers

the EWP by following certain cutting schemes of the raw panels. Concerning mechanical properties of SWP in bending, the standard asks for only one specimen per panel and grain direction of the face layers to be tested, respectively. EN 13353 (CEN 2003c), being relevant for the requirements on SWP, allows this respective test value to be taken as the mean value of the gross panel and for using this value "for all statistical calculations where the mean value and the variation of the mean values of the panels are used". It is however said that "the variation within a panel and the according calculations cannot be done" which means that e.g. characteristic values cannot be assigned to SWP based on this procedure. It is obvious that deriving mechanical properties from one single test is not sufficiently reliable. In scientific studies, tests of strip-shaped specimens may serve to verify assumptions with regard to material properties (e.g. Poisson's ratios, shear moduli, etc.) and in the course of production control such tests are useful to check e.g. adequate quality of bonding and can thus serve as a kind of "red light alert". However, cutting these strips off full panels is equal to a loss in material, and hence, in the producer's view respective width of specimens should be as small as possible. On the other hand the bending stiffness derived from the tests should still be a reliable indicating property for the stiffness of the gross panel.

\subsection{Aim of the study}

By comparing results of bending tests of $100 \mathrm{~mm}$ and $300 \mathrm{~mm}$ wide strip-shaped specimens with respective properties of full CLT panels, the presented study therefore aimed at evaluating if flexural stiffness properties of gross CLT panels can be reliably derived by testing strip-shaped specimens cut from the panels and to what extent the member width influences the test result.

\section{Material}

\subsection{Panels}

The study comprised a total of 42 CLT panels with different lay-ups and geometrical dimensions frequently used for load-bearing structural elements in Switzerland (Table 1). The panels were supplied by two producers (A and B) and exhibited remarkable differences in appearance and mechanical properties although the raw material was in both cases visually strength graded Norway spruce (Picea abies Karst.). This can be explained by the different ways of production of the panels.

The face layers of product A (Fig. 2, left) correspond to strength class C24 (EN 338; CEN 2003a), whilst the inner layers consist of $\mathrm{C} 20$ lamellas. In a first step glulam-like beams are produced by assembling lamellas (boards, if necessary finger-jointed) with a thickness of up to $70 \mathrm{~mm}$. The "glulam" is then vertically cut into planks (the width of them being equal to the height of the "glulam beams") which are used as face layers of the CLT panels. In this study, the width of the "lamellas" in the face layers was $70 \mathrm{~mm}$. The smaller sides of these planks are not bonded. The inner layers of the CLT panels consist of single lamellas with a width of 100 to $150 \mathrm{~mm}$ which at their smaller sides are not adhesively bonded. If the thickness of the inner layers is more than $30 \mathrm{~mm}$, grooves are cut into the inner layers in order to guarantee a sufficient strength of the bond line when processing the panel at low stresses perpendicular with a vacuum press. The moisture content (MC) of the wood is $12 \%$ to $14 \%$. All bonds are made with a 1-component-PUR adhesive.

CLT product B (Fig. 2, right) is made from mature wood lamellas of at least strength class C24 with narrow annual rings and higher density, MOE and strength compared to juvenile wood. In both face and inner layers the width of the 
Fig. 2 Investigated CLT products A (left) and B (right), example of thickness $70 \mathrm{~mm}$ Abb. 2 Untersuchte Brettsperrholz-Produkte A (links) und B (rechts) am Beispiel einer $70 \mathrm{~mm}$ dicken Platte

Fig. 3 Schematic of cutting strip-shaped specimens of CLT panels (series 1: left, series 2: right). Arrow indicates the grain direction of the face layers Abb. 3 Schema zur Abtrennung von Streifen aus Brettsperrholzplatten (Versuchsreihe 1: links, Versuchsreihe 2: rechts). Die Pfeile zeigen die Faserrichtung der Decklagen an
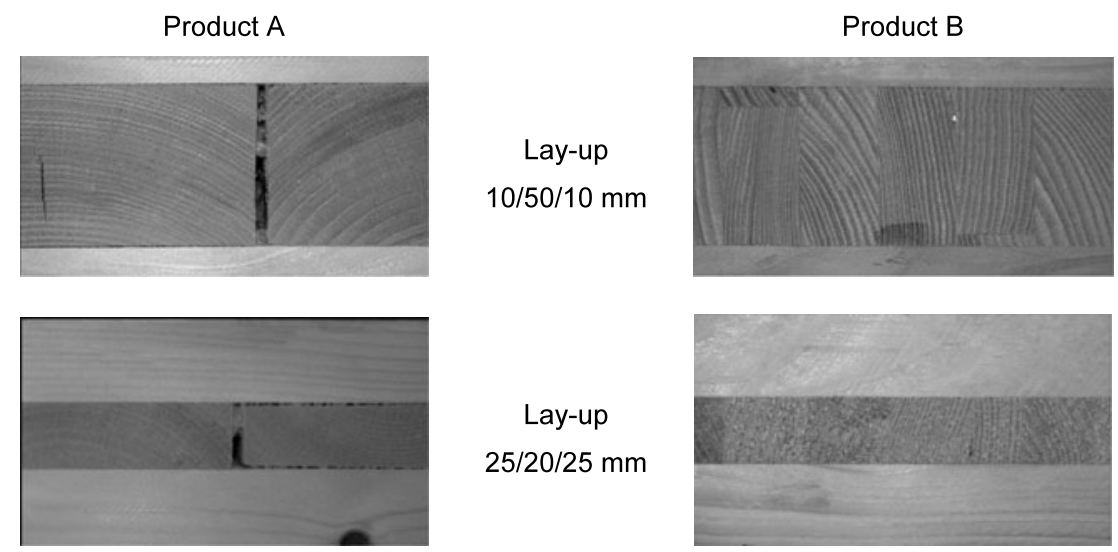

Lay-up

$25 / 20 / 25 \mathrm{~mm}$
Series $1-$ CLT panels
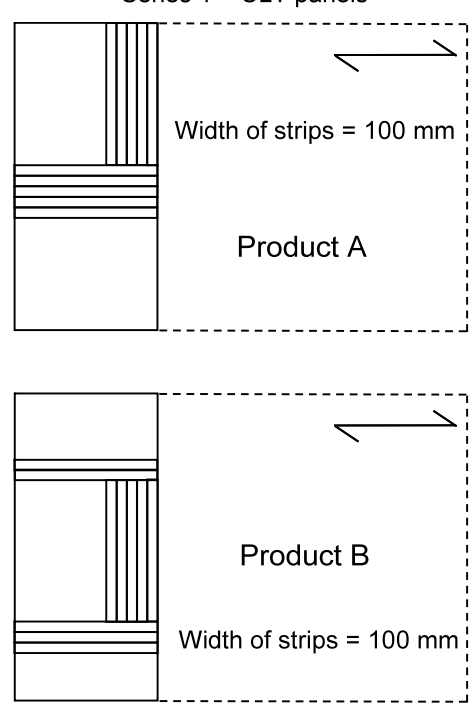

Series 2 - CLT panels
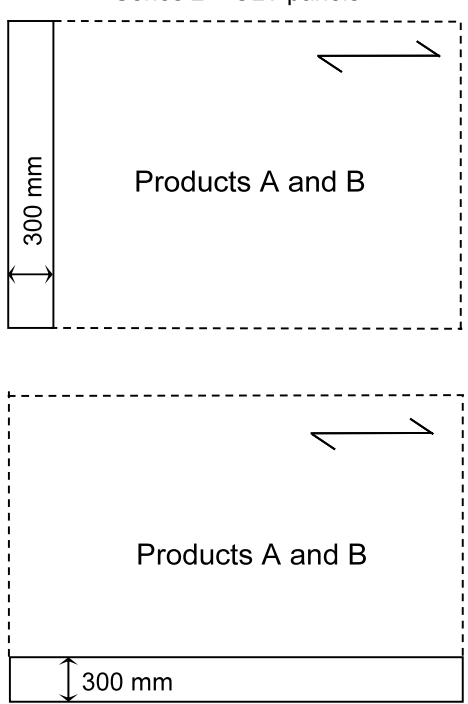

lamellas is $25 \mathrm{~mm}$. Before assembling the CLT, planking are produced by side bonding single $25 \mathrm{~mm}$ wide lamellas. Making sure that there is a sufficient lengthwise overlap of the single planking elements, several plankings are bonded glulam-like resulting in "Blockholz" which is then vertically cut into layers being the raw material for the CLT production. All bonds are made with a MUF type adhesive and the MC of the wood is $8 \%$. Compared to product A, due to smaller sized components of the layers, lacking of grooves and due to bonding of the layers on all sides, a higher degree of homogenization with product $\mathrm{B}$ can be expected.

Prior to testing in the lab, the CLT panels were stored in climate $20^{\circ} \mathrm{C} / 50 \%$ relative humidity of surrounding air $(\mathrm{RH})$, which resulted in an equilibrium moisture content of slightly below $12 \%$. The relative humidity was chosen different from the standard value of $65 \pm 5 \%$ (CEN 2003b) in order to prevent product B from too big changes in $\mathrm{MC}$.

\subsection{Strip-shaped specimens}

The schematic of cutting the strip-shaped specimens parallel and perpendicular to the grain direction of the face layers from the series $1-$ CLT panels (Table 1, top) is shown in Fig. 3, left. The panels were originally produced in rectangular shape and got quadratic $\left(2.50 \times 2.50 \mathrm{~m}^{2}\right)$ after cutting off the strip-shaped specimens. The width of the 5 to 6 strips per direction was $100 \mathrm{~mm}$. In the course of test series 2 (Table 1, bottom), two $300 \mathrm{~mm}$ wide strips (one per grain direction of the face layers) were cut from each panel according to Fig. 3, right. The strip-shaped specimens were stored in climate $20^{\circ} \mathrm{C} / 65 \% \mathrm{RH}$. 


\section{Method}

3.1 Assessing the elastic properties of the gross CLT panels

\subsubsection{Method}

To derive stiffness properties of gross CLT panels a method was applied which had recently been studied and further developed by Gsell et al. (2007) and Gülzow et al. (2008). The method is non-destructive and is based on experimental and theoretical modal analysis. It was reported that this method is an efficient and accurate technique to determine elastic stiffness elements of panel-shaped EWP (Bastos et al. 2002; Frederiksen 1997a, 1997b, 1997c; Larsson 1997). The procedure is based on three major steps (Gsell et al. 2007):

- First, an experimental modal analysis was performed on panels vertically suspended by thin wires and excited perpendicular to the plane: Resonance frequencies $f_{i, \exp }$ and mode shapes of the panels were evaluated.

- In a second step, resonance frequencies $f_{i, c a l}$ and modeshapes of the free vibrating, linear elastic panel were described in a theoretical model as functions of the elastic material properties using a higher order plate theory for the orthotropic case. Since shear deformations play an important role in CLT, the Reddy model (Reddy 1984) was taken in order to be able to account for such deformations. In the model the panel was assumed to be homogeneous but orthotropic.

- Finally, the inverse problem was solved by systematically adjusting the unknown stiffness properties until the theoretically calculated resonance frequencies $f_{i, c a l}$ fitted the experimentally measured ones $f_{i, \exp }$. In this optimization process, the stiffness values were estimated simultaneously using a parametric model fitting algorithm. In the first few iteration steps the computed and measured frequencies and mode shapes did not coincide, since the initial values of the material parameters were only rough estimates. Matching of mode shapes therefore was needed by a procedure based on MAC (Modal Assurance Criterion) values (Maia and Silva 1997).

\subsubsection{Verification}

In the course of applying and further developing the method, experiments were first performed under lab conditions on one single panel consisting of 3 layers $(10 / 50 / 10 \mathrm{~mm})$ with geometrical dimensions of $1.00 \times 1.50 \times 0.07 \mathrm{~m}^{3}$ (Gsell et al. 2007). An experimental verification with a static bending test showed that the method was able to correctly evaluate the relevant stiffness parameters of the CLT panel. Afterwards this was proven again for another 42 CLT panels of different geometrical dimensions and lay-ups (Table 1) (Gülzow 2008; Steiger et al. 2008). It was found that the

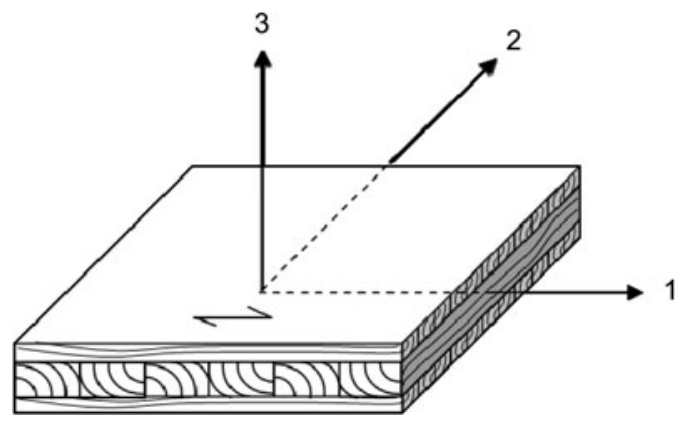

Fig. 4 Principal axis in CLT as used in this paper

Abb. 4 In diesem Beitrag verwendete Hauptachsenrichtungen von Brettsperrholz

method is capable of deriving two "homogenized" elastic moduli $\left(E_{11}, E_{22}\right)$ and the three "homogenized" shear moduli $\left(G_{12}, G_{13}, G_{23}\right)$ of the CLT panels. The corresponding directions of the principal axis are shown in Fig. 4.

When comparing stiffness properties derived dynamically (by modal analysis) and such derived by static testing, it has to be taken into account that parameters derived by means of dynamic methods due to the high speed of action (frequencies up to $300 \mathrm{~Hz}$ ) are approximately 6\% higher than those determined on the basis of static experiments at comparably lower loading rate (Görlacher 1984; Machek et al. 2001).

\subsection{Proof loading of the CLT panels to assess bending stiffness}

The elastic parameters of the CLT panels assessed by modal analysis were verified by static bending tests under different loading configurations (Table 2) (Gülzow et al. 2008; Steiger et al. 2008), the panels being simply supported at their 4 edges and up lifting being prevented. This verification revealed that the elastic parameters relevant for the serviceability design of CLT panels could be derived with sufficient precision by the modal analysis. Differences in panel stiffness of products A and B could be identified. The different ways of producing the panels (manifested as grooves, layers without lateral bonds, end jointing of lamellas without overlap nor fingers, etc.) were found to be of decisive influence on the stiffness properties of the panels.

\subsection{Bending tests of strip-shaped specimens}

\subsection{1 $100 \mathrm{~mm}$ wide strips (test series 1)}

4-point bending tests to assess bending stiffness were carried out with a span of $1100 \mathrm{~mm}(=15.7 \mathrm{~h})$ and a distance between the loading points of $300 \mathrm{~mm}(=4.29 \mathrm{~h})$ (Fig. 5, left) (Czaderski et al. 2007; Howald and Niemz 
Table 2 Loading configurations for bending tests of the CLT panels and codification of specimens

Tab. 2 Laststellungen bei den Biegeversuchen an den Brettsperrholzplatten und Bezeichnung der Prüfkörper (Platten)

Series Loading configurations, ${ }^{\text {a }}$ lay-ups of panels

Series 1:

Quadratic panels

$2.50 \times 2.50 \mathrm{~m}^{2}$
4 single loads

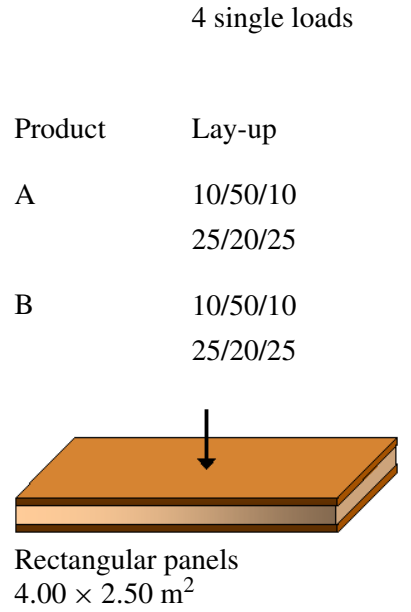

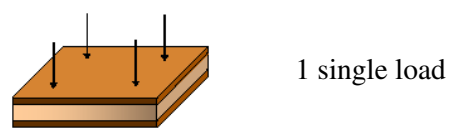

Panels

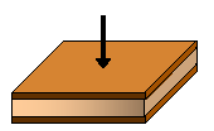

Panels

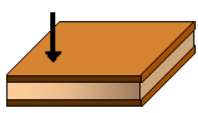

Panels
A1-A3
$10 / 50 / 10$
A7-A9
A10-A12

A4-A6

B13-B15

$10 / 50 / 10$

B19-B21

B22-B24

Series 2:

B16-B18

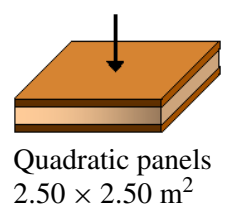

aLoads were located either in the center of the panel or in the center of the panel's quadrant(s)
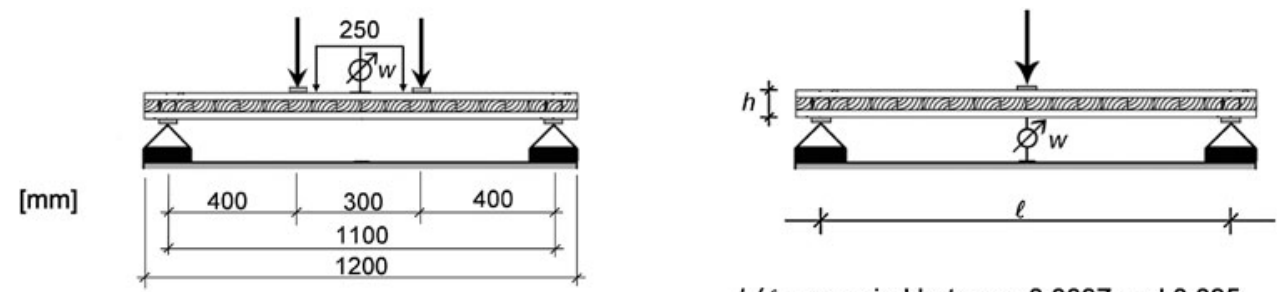

$h / \ell$ was varied between 0.0037 and 0.035 .

(h: see Table 1,)

Fig. 5 4-point bending tests on strip-shaped specimens in test series 1 (Howald and Niemz 2006) (left) and 3-point bending tests in series 2 (Gülzow 2008) (right)

Abb. 5 4-Punkt Biegeversuche an Streifen entnommen aus Brettsperrholzplatten der Versuchsreihe 1 (Howald and Niemz 2006) (links) und 3-Punkt-Biegeversuche an Streifen entnommen aus Brettsperrholzplatten der Versuchsreihe 2 (Gülzow 2008) (rechts)

2006). Hence, except the distance between the loading points (which should be one third of $15.7 h$ ) the EN 408 regulations were met. The reference loads to determine the moduli of elasticity (MOE) were (as requested by EN 408) $10 \%$ and $40 \%$ of the expected failure load. The deformations were measured between the loading points on the upper side of the specimens with a gauge length of $250 \mathrm{~mm}$ (Fig. 5, left). Speed of the loading head was within the limits given by EN 408.

\subsection{2 $300 \mathrm{~mm}$ wide strips (test series 2)}

The MOE in bending and the shear modulus were evaluated according to EN 408 with the specimens having a width of $300 \mathrm{~mm}$. The shear moduli $G$ (below referred to as $G_{13}$ and $G_{23}$ ) and the MOE $E_{m \text {,mean }}$ (below referred to as $E_{11}$ and $\left.E_{22}\right)$ were determined by the variable span method ac- cording to EN 408 from the apparent MOE $E_{m, a p p}$ for each test piece. Along this method, 3-point bending tests are performed and the midpoint deflection consisting of a bending deformation part and a shear deformation part is measured. The test arrangement is shown in Fig. 5, right. From the midpoint deflection an apparent MOE $E_{m, a p p}$ can be derived. The influence of shear deformation is known to depend on the span $(\ell)$ to depth $(h)$ ratio of the beam. If the inverse of $E_{m, a p p}$ is graphed against $(h / \ell)^{2}$ the local MOE $E_{m, l}$ (lacking of any influence of shear deformation!) can be derived from the intersection of the regression line and the ordinate as shown in Fig. 6.

In the tests the depth to span ratio was varied in 4 steps between $h / \ell=0.0037$ and 0.035 . The deformations were measured for $10 \%$ and $40 \%$ of the expected failure load and speed of loading was such that each test lasted 1 minute, which is slightly above the minimal test duration requested 


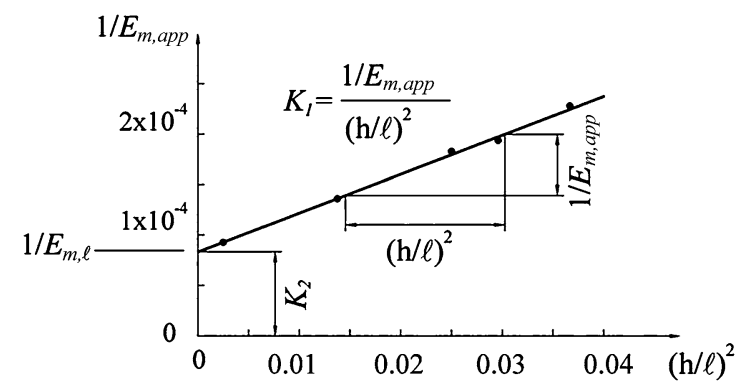

Fig. 6 Determination of the local MOE $E_{m, \ell}$ and the shear modulus $G$ from the apparent MOE $E_{m, a p p}$ by means of the variable span method according to EN 408 (CEN 2003b)

Abb. 6 Ermittlung des lokalen Elastizitätsmoduls $E_{m, \ell}$ und des Schubmoduls $G$ aus dem scheinbaren Elastizitätsmodul $E_{m, a p p}$ mittels Biegeprüfungen bei variabler Spannweite gemäß EN 408 (CEN 2003b)

by EN 408. Strips with grooves and cuts (which aim at reducing warping due to changing moisture) were tested twice with changing orientation of tension and compression side.

\section{Results and discussion}

\subsection{MOE of $100 \mathrm{~mm}$ wide strips (test series 1)}

Figure 7 shows mean, maximum and minimum values of the MOE $E_{11}$ and $E_{22}$ of 5 to 6 strips per panel and grain direction of the face layers. Left portions of the diagrams reflect test results of product $\mathrm{A}$ and right portions those of product B. For lay-up 10/50/10 $\mathrm{mm}$ the respective sample sizes were for product A: $n_{E_{11}}=57, n_{E_{22}}=59$ and for product B: $n_{E_{11}}=59, n_{E_{22}}=57$. The lay-up 25/20/25 mm sample sizes for product A amounted to: $n_{E_{11}}=18, n_{E_{22}}=18$ and for product $\mathrm{B}$ to: $n_{E_{11}}=17, n_{E_{22}}=18$.

The coefficients of variation $(\mathrm{CoV})$ clearly indicate a large variation of the stiffness properties within single CLT panels independent of their lay-up. These big variations result from the heterogeneity of the raw material becoming more evident when testing small strip-shaped specimens. Maximum CoV of $E_{11}$ of strip test samples within one CLT panel was $16.7 \%$ for product A and $18.7 \%$ for product B. In case of $E_{22}$ these values were $32.8 \%$ (product $A$ ) and $12.2 \%$ (product $\mathrm{B}$ ). Respective mean values of $\mathrm{CoV}$ were for $E_{11} 11.6 \%$ (product A) and $12.8 \%$ (product B) and for $E_{22} 14.8 \%$ (product A) and $9.6 \%$ (product B).

The mean values of the strip test samples can be compared to the respective values derived by modal analysis of the gross CLT panel. The maximal difference is $20.6 \%$ for strips tested parallel to the grain direction of the face layers $\left(E_{11}\right)$ and $13.8 \%$ perpendicular to it $\left(E_{22}\right)$. Thereby no clear trend of over- or underestimating could be found. Thus it is hardly possible to derive accurate stiffness properties of CLT panels by testing one single or a few $100 \mathrm{~mm}$ wide stripshaped specimens. On average (mean values of all stripshaped specimens cut from the same panel) the differences are for $E_{11} 10.2 \%$ (product A) and 6\% (product B) and for $E_{22} 6.9 \%$ (product $\mathrm{A}$ ) and $7.8 \%$ (product $\mathrm{B}$ ). This can be sufficient for civil engineering design practice but occurring maximal differences of $20 \%$ in specific cases lead to wrong results in calculation of deformations and hence highlight the shortcomings of tests on strip-shaped specimens with a width of $100 \mathrm{~mm}$.

When plotting all series of the CLT panels with lay-up $10 / 50 / 10 \mathrm{~mm}$ in normal probability plots (NPP) (Fig. 8) it can be seen that the mean values of the MOE of the strip tests are marginally higher than the ones derived by modal analysis of the gross panel. The numerical representation of the respective data (Table 3) exhibits differences in mean values of $E_{11}$ of $+1.5 \%$ for product A and $+2.7 \%$ for product B. In case of $E_{22}$ the differences are $+5.4 \%$ (product A) and $+8.3 \%$ (product $\mathrm{B}$ ). Comparing the slopes of the linear regression lines in the NPP, much bigger variability of the strip test samples is obvious. Overall variations are higher in product $\mathrm{A}$ than in product $\mathrm{B}$ which can be explained by a different degree of homogenization due to the different ways of production and due to the quality of the raw material (see Sect. 2.1).

\subsection{MOE and shear moduli of $300 \mathrm{~mm}$ wide strips (test} series 2)

Generally, linear regression lines in plots of $1 / E_{m, a p p}$ versus $(h / \ell)^{2}$ (Fig. 6) exhibited high coefficients of determinations indicating that the derived MOE and shear moduli are of high accuracy. However, some single values in the test series with strips oriented perpendicular to the grain direction of the face layers did not well fit the trend line, this being due to opening of joints at lamella contacts which were not adhesively bonded (Fig. 9, left). Consequently respective test results were excluded from analysis and the MOE was derived from tests with 3 aspect ratios $h / \ell$ only (Fig. 9, right).

Figure 10 shows a comparison of $\operatorname{MOE}\left(E_{11}, E_{22}\right)$ and shear moduli $\left(G_{13}, G_{23}\right)$ derived by modal analysis of the gross CLT panels and by bending tests of the $300 \mathrm{~mm}$ wide strip-shaped specimens cut from the respective panels according to Fig. 3, right. The diagonal line in Fig. 10 indicates the ideal case, where parameters derived with both methods are equal. Overall, the differences independently from type of product are small to moderate. Parameter $E_{22}$ even shows a very good agreement. A closer look on the specimens exhibiting bigger differences revealed that these differences mainly resulted from striking non-homogeneities in the used raw material. The biggest difference in $E_{11}(60 \%)$ occurred with panel R_0.08_3L_A_P1. A detailed analysis of the reasons for this big difference showed up defects (knots, pitch 
$E_{11}$ - Panels of lay up $10 / 50 / 10$

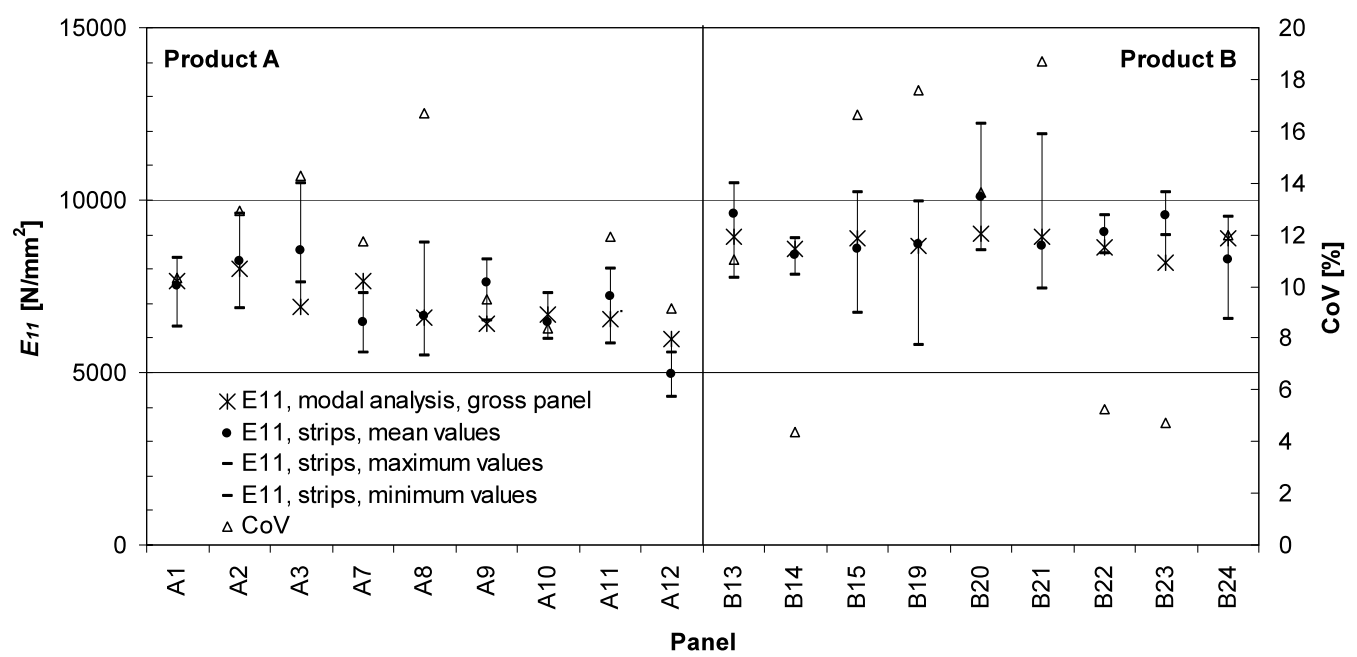

$E_{22}$ - Panels of lay up 10/50/10

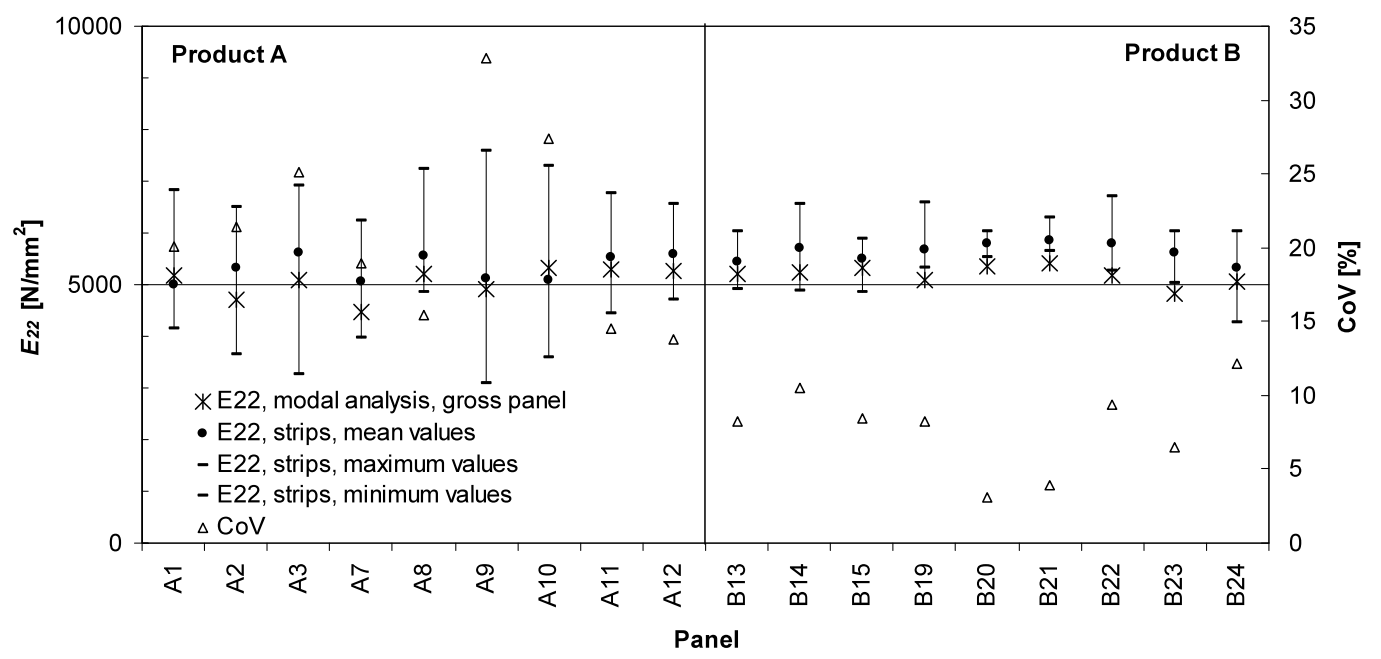

$E_{11}$ - Panels of lay up $25 / 20 / 25$

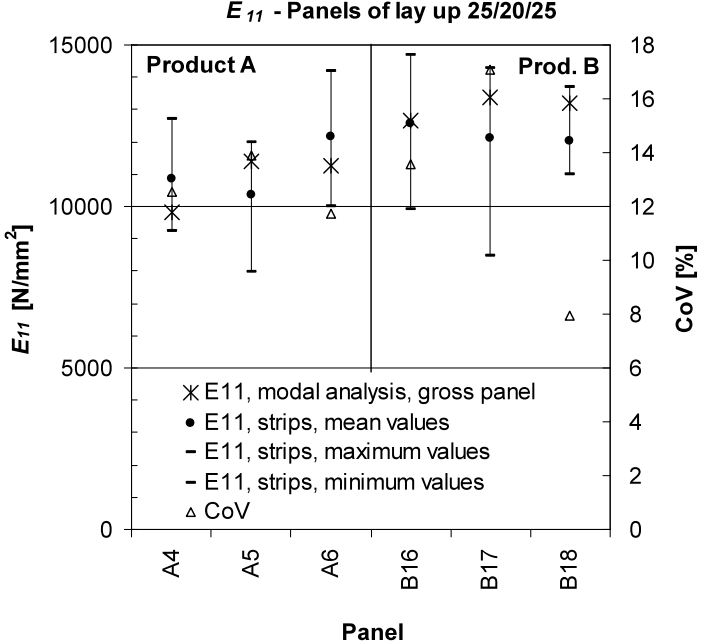

$E_{22}$ - Panels of lay up $25 / 20 / 25$

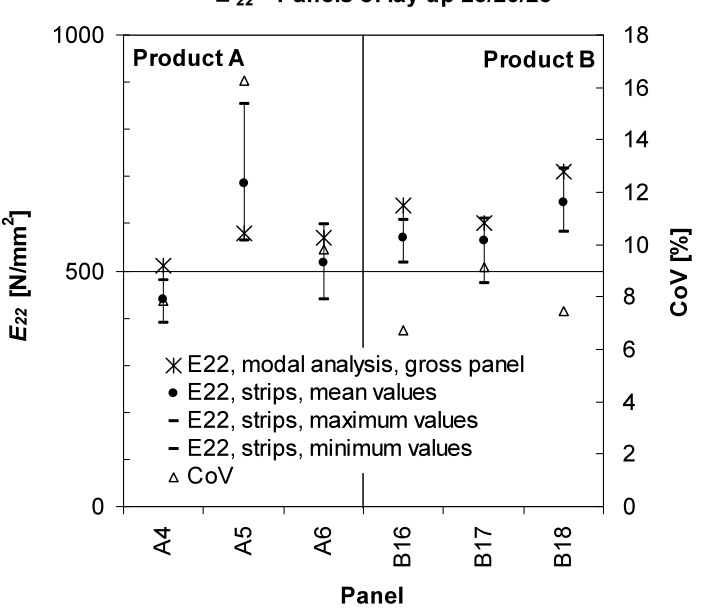

Fig. 7 MOE $E_{11}, E_{22}$ derived by 4-point bending tests of $100 \mathrm{~mm}$ wide strip-shaped specimens (5-6 specimens per series $1-\mathrm{CLT}$ panel) or by modal analysis of gross CLT panels ( $($-signs) together with respective coefficients of variation $(\mathrm{CoV})$

Abb. 7 Elastizitätsmoduln $E_{11}, E_{22}$ und zugehörige Variationskoeffizienten $(\mathrm{CoV})$ ermittelt aus 4-Punkt-Biegeversuchen an $100 \mathrm{~mm}$ breiten Plattenstreifen (5 bis 6 Prüfkörper pro Brettsperrholzplatte der Versuchsreihe 1) bzw. aus einer Modalanalyse an der ganzen Brettsperrholzplatte (Symbol: $*)$ 

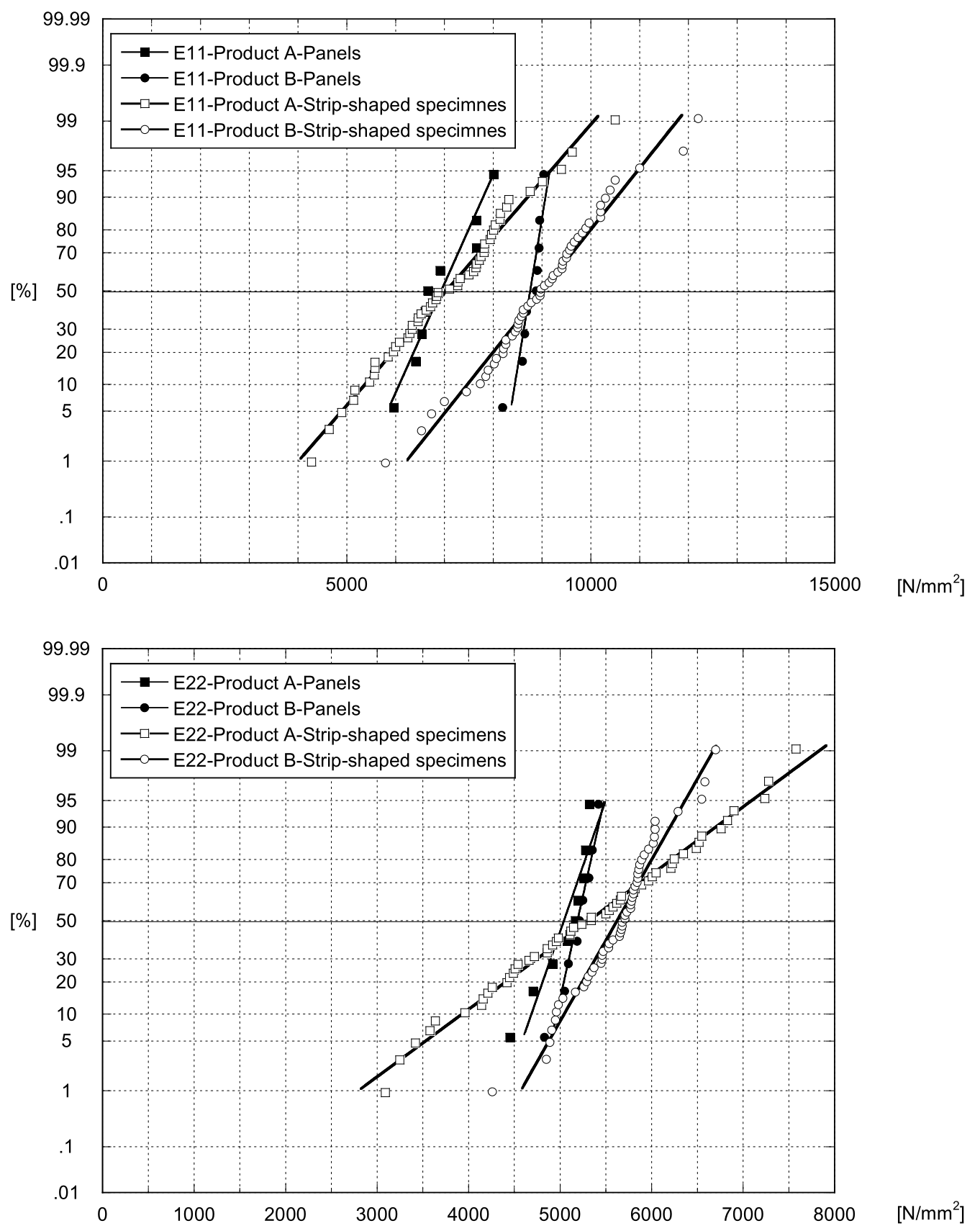

Fig. 8 Comparative normal probability plot of bending MOE $E_{11}$ (top) and $E_{22}$ (bottom) derived from 4-point bending tests of $100 \mathrm{~mm}$ wide strip-shaped specimens (5 to 6 specimens per series 1-CLT panel) and by modal analysis. (Panels with lay-up 10/50/10 mm only)

Abb. 8 Vergleichende Darstellung der Biege-E-Moduln $E_{11}$ (oben) und $E_{22}$ (unten) ermittelt anhand von 4-Punkt-Biegeversuchen an 100 mm breiten Plattenstreifen ( 5 bis 6 Prüfkörper pro Brettsperrholzplatte aus der Versuchsreihe 1) in Wahrscheinlichkeitsnetzen mit normalverteilter Ordinate (nur Platten mit Aufbau 10/50/10 mm)

pockets and deviated grain) (Fig. 11) which partly affected whole layers resulting in a severe reduction of the stiffness of the face layers. In order to ensure good quality of data, specimens with such big cuts and grooves were loaded twice with changing orientation of the tension side in bending. Table 4 shows a comparison of respective test results. Overall the differences are below $5 \%$, except for shear modulus
$G_{13}$ of panel R_0.08_5L_B_P3 $(13.7 \%)$. Thus it can be concluded that the test procedure did not systematically affect the data.

Regarding Fig. 10 it has to be added that the big differences in parameter $G_{23}$ (being a combination of the rolling shear modulus of the face layers and of the shear modulus of the middle layer) mainly result from difficulties in 
Table 3 Statistical parameters of the data shown in Fig. 8

Tab. 3 Statistische Kennwerte der Daten aus Abb. 8

\begin{tabular}{|c|c|c|c|c|c|}
\hline & & Sample size & Mean value & Standard deviation & $\mathrm{CoV}$ \\
\hline \multirow[t]{2}{*}{$E_{11}$ of product A } & Strip-shaped specimens & 52 & 7040 & 1300 & $18.5 \%$ \\
\hline & Panels & 9 & 6940 & 690 & $9.9 \%$ \\
\hline \multirow[t]{2}{*}{$E_{11}$ of product B } & Strip-shaped specimens & 54 & 9000 & 1200 & $13.3 \%$ \\
\hline & Panels & 9 & 8760 & 260 & $3.0 \%$ \\
\hline \multirow[t]{2}{*}{$E_{22}$ of product $\mathrm{A}$} & Strip-shaped specimens & 53 & 5320 & 1080 & $20.4 \%$ \\
\hline & Panels & 9 & 5040 & 300 & $5.8 \%$ \\
\hline \multirow[t]{2}{*}{$E_{22}$ of product B } & Strip-shaped specimens & 52 & 5620 & 460 & $8.2 \%$ \\
\hline & Panels & 9 & 5190 & 180 & $3.5 \%$ \\
\hline
\end{tabular}
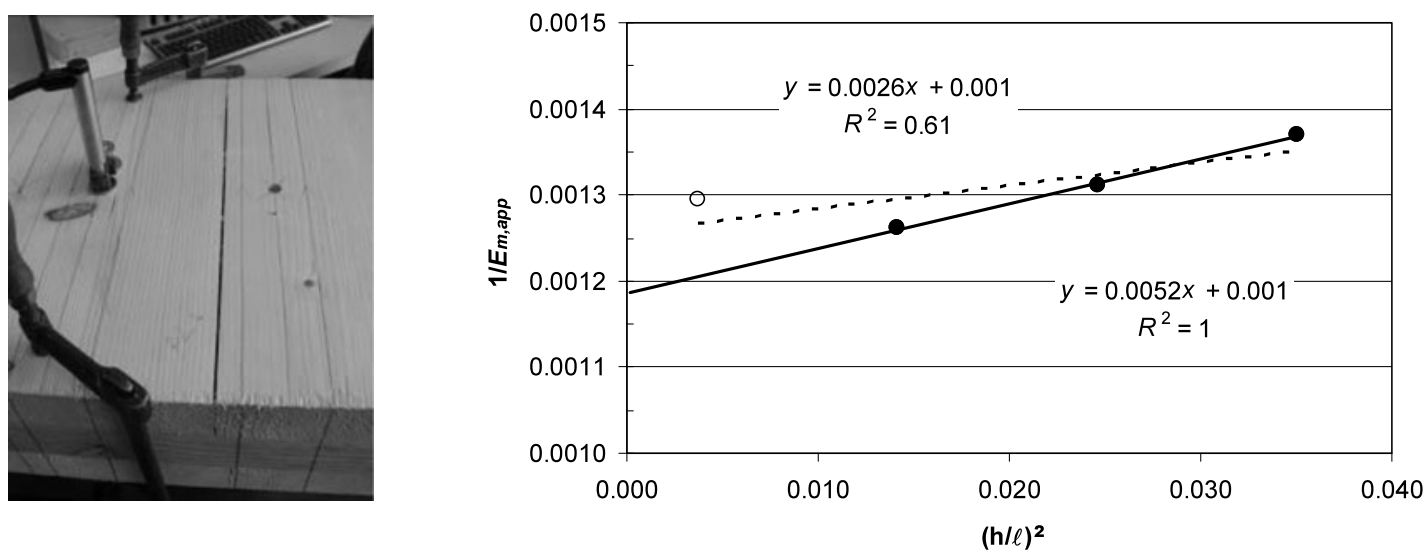

Fig. 9 Deriving of MOE and shear moduli on strips perpendicular to the face layers of the CLT panels from regression lines of $1 / E_{m, a p p}$ versus $(h / \ell)^{2}($ right $)$ concentrated only on test results (marked with $\bullet$ ) not being influenced by opening of not adhesively bonded joints $(l e f t)$. Test results of strips with open joints are marked with o

Abb. 9 Die E-Moduln und Schubmoduln wurden aus Regressionslinien des Zusammenhangs von $1 / E_{m \text {,app }}$ mit $(h / \ell)^{2}$ gewonnen $($ rechts, Markierung •). Dabei wurden Versuchsdaten vernachlässigt, welche von Prüfkörpern mit offenen Fugen oder Rissen in den Deckschichten stammten (links). Im Bild rechts sind solche Versuchsdaten mit o markiert

deriving this parameter by modal analysis since $G_{23}$ does not have noticeable influence on the mode shapes and resonance frequencies (Gülzow et al. 2008). However, bending tests of strip-shaped specimens with variable span are also not capable of deriving actual $G_{23}$ values since grooves and layer sides not adhesively bonded exhibited different stiffness when being positioned at free span or near the supports respectively. At least the bending tests confirmed the same range of the $G_{23}$ values derived by modal testing.

4.3 Comparison of the accuracy of tests on $100 \mathrm{~mm}$ wide strips and $300 \mathrm{~mm}$ wide ones to derive MOE

Table 5 shows the differences between the MOE $E_{11}$ and $E_{22}$ derived from modal testing of gross panels and from respective strips. Average values of 5-6 $100 \mathrm{~mm}$ wide strips (referring to a total width tested of at least $500 \mathrm{~mm}$ ) are capable of estimating the MOE $E_{11}$ and $E_{22}$ with a surprisingly high precision. Taking the mean value of all tested panels, the difference is only $8 \%$ and mainly results from the different speed of action when deriving the elastic properties (see Sect. 3.1.2). The respective product specific differences are $9 \% / 6 \%\left(E_{11}\right.$ of product $\left.\mathrm{A} / \mathrm{B}\right)$ and $9 \% / 8 \%$ ( $E_{22}$ of product $\mathrm{A} / \mathrm{B})$. Due to a higher degree of homogenization the differences for product $\mathrm{B}$ are smaller than for product $\mathrm{A}$.

However, testing single strips only leads to less reliable results. The differences for single $100 \mathrm{~mm}$ wide strips account for less than 5\% (best case) or more than 50\% (worst case). The $300 \mathrm{~mm}$ strip test series only showed good results in case of product B (difference in $E_{11}: 8 \%$ and in $E_{22}: 4 \%$ ). Less homogenized product A exhibited differences of $17 \%$ in $E_{11}$ and $10 \%$ in $E_{22}$.

\section{Conclusion}

Based on the reported comparative assessment of bending stiffness of gross CLT panels and strip-shaped specimens of 
$E_{11}$

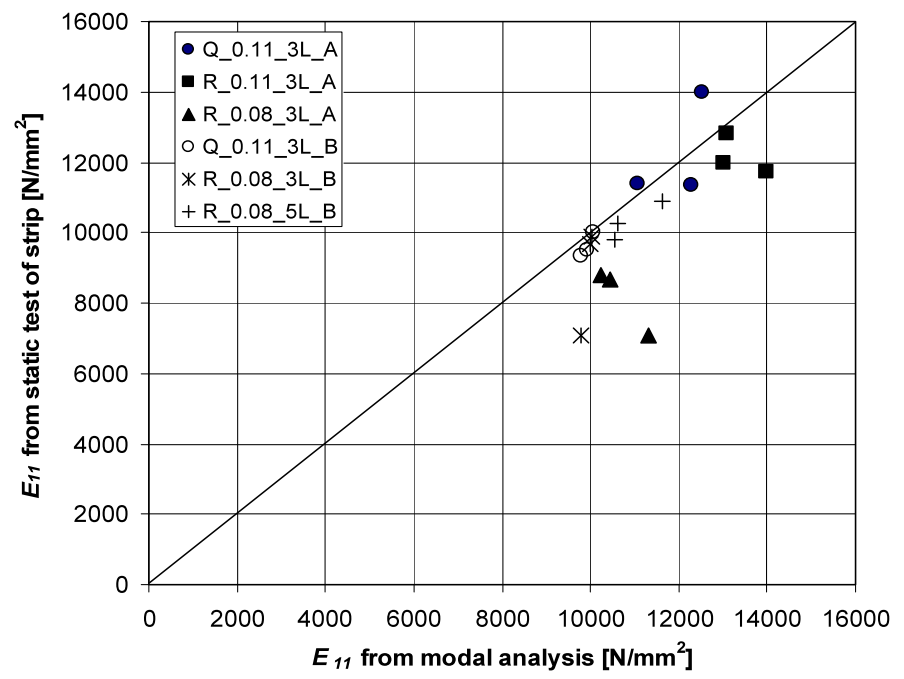

$\mathbf{G}_{13}$

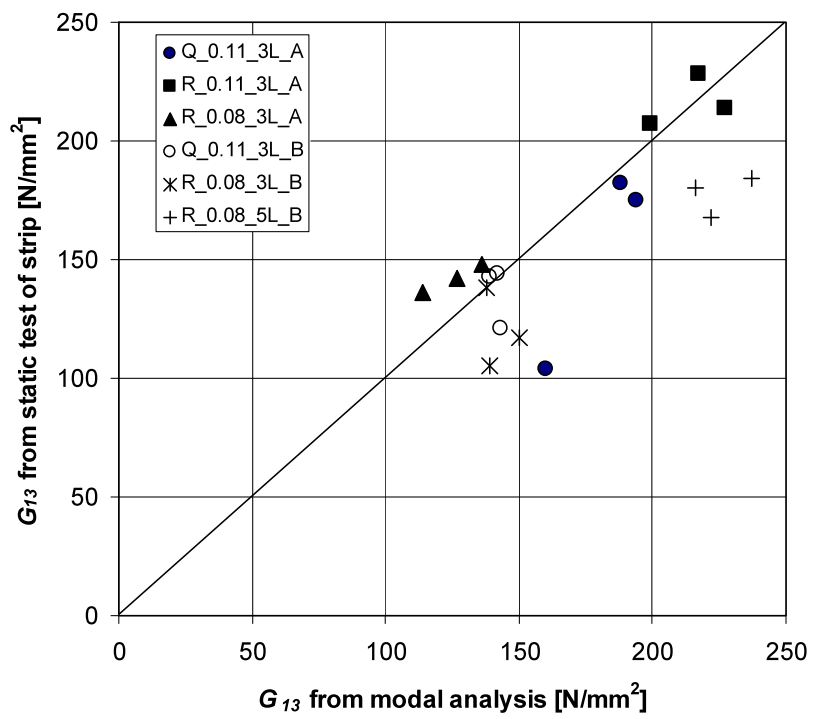

$E_{22}$

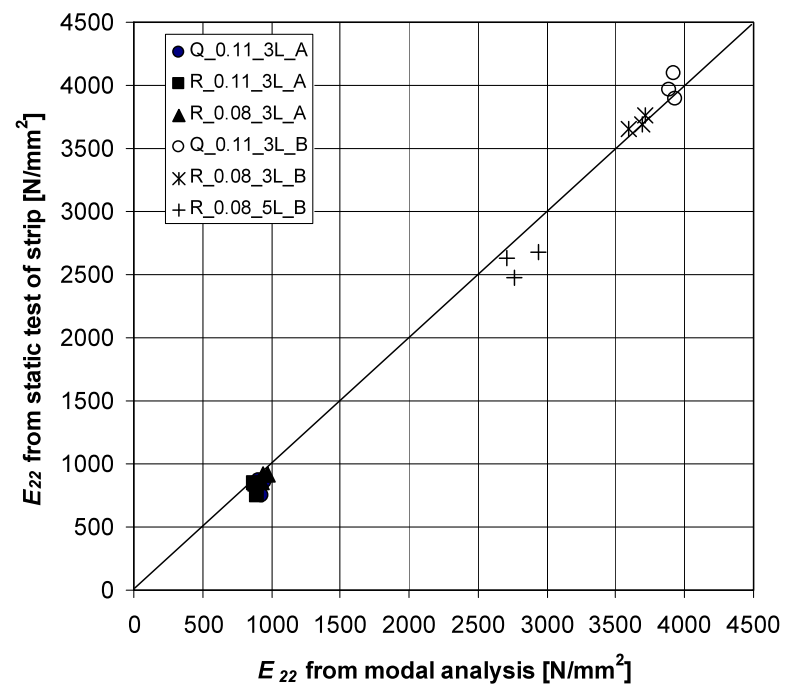

$\mathbf{G}_{23}$

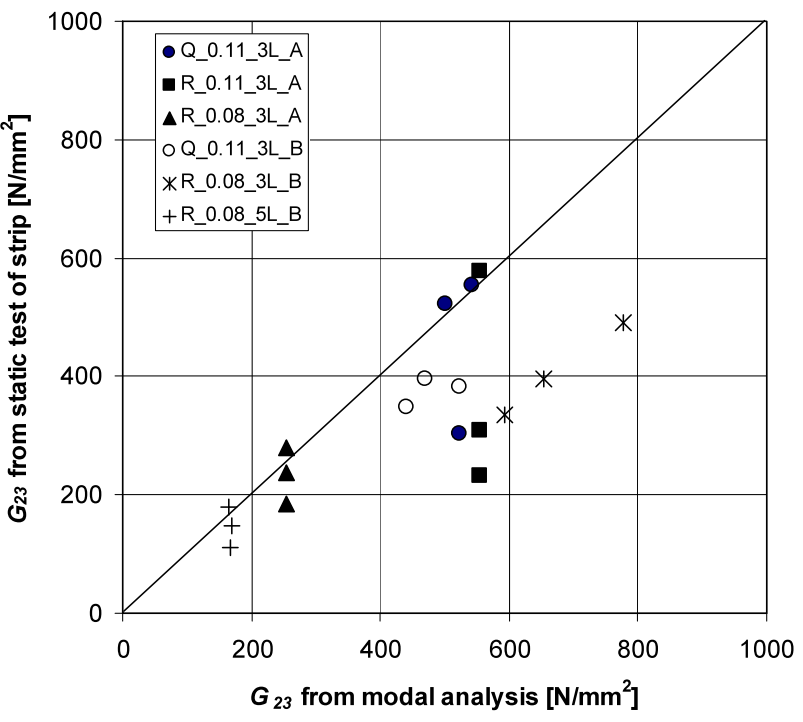

Fig. 10 Comparison of MOE and shear moduli derived by modal analysis of the gross CLT panels and by bending tests of 300 mm wide single strip-shaped specimens cut from the respective panels according to Fig. 3, right (test series 2). (Labels: Q/R $=$ quadric/rectangular panel $2.50 \times 2.50 \mathrm{~m}^{2} / 4.00 \times 2.50 \mathrm{~m}^{2}, 0.11 / 0.08=$ panel thickness $[\mathrm{m}], 3 \mathrm{~L} / 5 \mathrm{~L}=3 / 5$ layers, $\mathrm{A} / \mathrm{B}=$ type of product)

Abb. 10 Vergleich der Elastizitäts- und Schubmoduln ermittelt aus einer Modalanalyse der ganzen BSP-Platten und aus Biegeversuchen an einzelnen $300 \mathrm{~mm}$ breiten Streifen aus den Platten entnommen gemäß Einschnittschema Abb. 3, rechts (Versuchsreihe 2). (Bezeichnungen: Q/R $=$ quadratische/rechteckige Platten $2,50 \times 2,50 \mathrm{~m}^{2} / 4,00 \times 2,50 \mathrm{~m}^{2}, 0,11 / 0,08=$ Plattendicke $[\mathrm{m}], 3 \mathrm{~L} / 5 \mathrm{~L}=3 / 5$ Lagen, A/B $=$ Produkttyp)

widths $100 \mathrm{~mm}$ or $300 \mathrm{~mm}$ cut off these panels the following conclusions could be drawn:

- Bending stiffness of CLT panels can vary quite strongly within one single panel.

- The accuracy of the stiffness properties derived by bending tests on strip-shaped specimens with a width of $300 \mathrm{~mm}$ (which is in line with EN 789) depended on type of product. Whereas for product $\mathrm{B}$ the differences were small to moderate, product A due to less homoge- nization exhibited higher deviations. Testing strip-shaped specimens with a width of $100 \mathrm{~mm}$ only led to acceptable results if tested as samples of 5 to 6 specimens.

- The variation of the stiffness properties depends on the degree of homogenization of the actual CLT product. The smaller the components (lamellas) and the less the variation in mechanical properties (which can be reached by adequate strength grading of the raw material), the better it can be concluded from tests on strip-shaped specimens to the bending stiffness of the gross CLT panel. 
- Compared to gross CLT panels, local non-homogeneities and defects (knots, pitch pockets, deviated grain, not adhesively bonded contacts, cuts, grooves and cracks) have more influence on the bending stiffness of the strip-

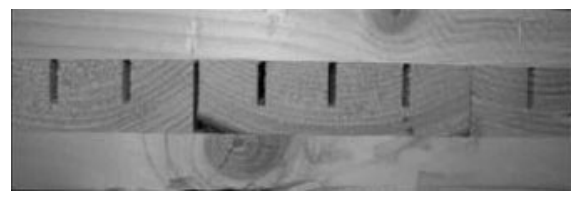

Fig. 11 Cross-section view of the strip taken from panel R_0.08_3L_A_P1: Knots, pitch pockets, deviated grain and grooves affect nearly the whole respective layers

Abb. 11 Querschnitt eines Streifens aus Platte R_0.08_3L_A_P1: Erkennbar sind Äste, Harztaschen, Schrägfasrigkeit und Kerben in sämtlichen 3 Lagen shaped specimens. The smaller the width of such specimens, the more their load-bearing behavior is affected by these local defects and non-homogeneities due to structural defects in the raw material or due to different ways of producing the panels.

- The distances between middle layer parts not adhesively bonded at their lateral sides and the number of cuts and grooves, which are aimed at reducing the deformations of the CLT panel in case of changing moisture, have a big influence on the shear moduli. When deriving respective values on base of testing strip-shaped specimens this possible variation has to be taken into account by using empirical relationships.

Single tests on strip-shaped specimens with a width of at least $300 \mathrm{~mm}$ therefore may well serve in quality con-

Table 4 Comparison of MOE and shear moduli of strip-shaped specimens with big cuts and grooves tested twice with changing orientation of the tension side

Tab. 4 Vergleich von Elastizitäts- und Schubmoduln aus der zweimaligen Prüfung von Plattenstreifen mit markanten Fugen bei wechselnder Orientierung der Zugzone

\begin{tabular}{lccc}
\hline Panel & $E_{11}\left[\mathrm{~N} / \mathrm{mm}^{2}\right]$ & $\Delta E_{11}$ & $G_{13}\left[\mathrm{~N} / \mathrm{mm}^{2}\right]$ \\
\hline R_0.08_3L_A_P1a & 7060 & $0.3 \%$ & 140 \\
R_0.08_3L_A_P1b & 7080 & & 130 \\
R_0.08_3L_A_P2a & 8680 & $0.6 \%$ & 150 \\
R_0.08_3L_A_P2b & 8630 & & 140 \\
R_0.08_3L_A_P3a & 8920 & $2.7 \%$ & 140 \\
R_0.08_3L_A_P3b & 8690 & & 150 \\
R_0.08_5L_B_P1a & 10860 & $0.3 \%$ & 170 \\
R_0.08_5L_B_P1b & 10890 & & 165 \\
R_0.08_5L_B_P2a & 10280 & $0 \%$ & 180 \\
R_0.08_5L_B_P2b & 10280 & & 180 \\
R_0.08_5L_B_P3a & 9580 & $4.6 \%$ & $2.4 \%$ \\
R_0.08_5L_B_P3a & 10020 & & 170 \\
\hline
\end{tabular}

Table 5 Comparison of the accuracy of test series 1 (100 mm wide strips) and 2 (300 mm wide strips) to derive MOE $E_{11}$ and $E_{22}$ of gross CLT panels

Tab. 5 Vergleich der Aussagekraft von Versuchen an Plattenstreifen der Serie 1 (100 mm) und Serie 2 (300 mm) bezüglich Elastizitätsmoduln $E_{11}$ und $E_{22}$ von Brettsperrholzplatten

\begin{tabular}{|c|c|c|c|c|c|c|}
\hline \multirow[t]{2}{*}{ Series } & \multicolumn{3}{|c|}{ Differences in $E_{11}$} & \multicolumn{3}{|c|}{ Differences in $E_{22}$} \\
\hline & All panels & Product A & Product B & All panels & Product A & Product B \\
\hline $\begin{array}{l}\text { Series } 1 \text { ( } 100 \mathrm{~mm} \text { strips): } \\
\text { Mean value of } 5-6 \text { strips }\end{array}$ & $8 \%$ & $9 \%$ & $6 \%$ & $8 \%$ & $9 \%$ & $8 \%$ \\
\hline Series 1 (100 mm strips): & \multicolumn{3}{|c|}{ Best case: $<5 \%$} & \multicolumn{3}{|c|}{ Best case: $<5 \%$} \\
\hline Single value out of 5-6 strips: & \multicolumn{3}{|c|}{ Worst case: $>50 \%$} & \multicolumn{3}{|c|}{ Worst case: $>50 \%$} \\
\hline Series 2 (300 mm strips) & $12 \%$ & $17 \%$ & $8 \%$ & $7 \%$ & $10 \%$ & $4 \%$ \\
\hline
\end{tabular}


trol after production or when assessing the stiffness of CLT parts acting as beam-like structural elements. Whereas the EN 789 test procedures might be adequate for SWP used as sheeting element, CLT requires test procedures similar to glulam or solid timber when directly used for load-bearing structures. Hence, respective rules and instructions should be added to future issues of EN 408 accounting for situations where CLT is used either as a panel-type element (loaded in plane or perpendicular to it) or as beam-type element (strip).

Acknowledgements The presented study was financially supported by the Swiss Federal Office for Professional Education and Technology OPET (innovation promotion agency CTI) and by the Swiss Federal Office for the Environment FOEN (Wald- und Holzforschungsfonds WHFF). The test panels were supplied by Pius Schuler AG, CH-6418 Rothenturm, Switzerland (www.pius-schuler.ch) and by Schilliger Holz AG, Haltikon 33, CH-6403 Küssnacht (www.schilliger.ch). The assistance of the Empa technicians B. Dürst, D. Heer, M. Heusser, H. Lippuner, B. Maag, M. Strässle and K. Weiss is gratefully acknowledged.

\section{References}

Altenbach H, Altenbach J, Rikards R (1996) Einführung in die Mechanik der Laminat- und Sandwichtragwerke: Modellierung und Berechnung von Balken und Platten aus Verbundwerkstoffen. Deutscher Verlag für Grundstoffindustrie, Stuttgart

Bastos SF, Borges L, Rochinha FA (2002) Numerical and experimental approach for identifying elastic parameters in sandwich plates. Shock Vib 9(4-5):193-201

Blass HJ, Görlacher R (2003) Bemessung im Holzbau: Brettsperrholz-Berechnungsgrundlagen. Holzbau-Kalender. Bruderverlag, Karlsruhe, pp 580-598

Bodig J, Jayne BA (1993) Mechanics of wood and wood composites. Krieger Publishing Company, Malabar

Czaderski C, Steiger R, Howald M, Olia S, Gülzow A, Niemz P (2007) Versuche und Berechnungen an allseitig gelagerten 3-schichtigen Brettsperrholzplatten. Holz Roh- Werkst 65(5):383-402

CEN (2001) EN 12775: Solid wood panels (SWP)—classification and terminology. European Committee for Standardization, CEN, Bruxelles, Belgium

CEN (2003a) EN 338: Structural timber-strength classes. European Committee for Standardization, CEN, Bruxelles, Belgium

CEN (2003b) EN 408: Timber structures-structural timber and glued laminated timber-determination of some physical and mechanical properties. European Committee for Standardization, CEN, Bruxelles, Belgium

CEN (2003c) EN 13353: Solid wood panels (SWP)—requirements. European Committee for Standardization, CEN, Bruxelles, Belgium

CEN (2004a) EN 789: Timber structures-test methodsdetermination of mechanical properties of wood based panels. European Committee for Standardization CEN, Bruxelles, Belgium
CEN (2004b) EN 1995-1-1 (Eurocode 5-1-1): Design of timber structures-Part 1-1: General-common rules and rules for buildings. European Committee for Standardization. CEN, Bruxelles, Belgium

CEN (2004c) EN 13986: Wood-based panels for use in constructioncharacteristics, evaluation of conformity and marking. European Committee for Standardization CEN, Bruxelles, Belgium

Frederiksen PS (1997a) Application of an improved model for the identification of material parameters. Mech Adv Mat Struct 4(4):297316

Frederiksen PS (1997b) Experimental procedure and results for the identification of elastic constants of thick orthotropic plates. J Compos Mater 31(4):360-382

Frederiksen PS (1997c) Numerical studies for the identification of orthotropic elastic constants of thick plates. Eur J Mech A, Solids 16(1):117-140

Görlacher R (1984) Ein neues Messverfahren zur Bestimmung des Elastizitätsmoduls von Holz. Holz Roh- Werkst 42(6):219-222

Gsell D, Feltrin G, Schubert S, Steiger R, Motavalli M (2007) Crosslaminated timber plates: evaluation and verification of homogenized elastic properties. J Struct Eng 133(1):132-138

Gülzow A (2008) Zerstörungsfreie Bestimmung der Biegesteifigkeiten von Brettsperrholzplatten. PhD Thesis Nr 17944. ETH Zürich, Switzerland

Gülzow A, Gsell D, Steiger R (2008) Zerstörungsfreie Bestimmung elastischer Eigenschaften quadratischer 3-schichtiger Brettsperrholzplatten mit symmetrischem Aufbau. Holz Roh- Werkst 66(1):19-37

Howald M, Niemz P (2006) Abschlussbericht zum KTI Projekt 5927.2, Komplex 1 "Berechnungsmodelle für Massivholzplatten". Ermittlung mechanischer Eigenschaften anhand von UltraschallMessungen und Biegeversuchen an Kleinproben, Teil 1. Institut für Baustoffe, ETH Zürich, Zürich

Jöbstl RA, Moosbrugger T, Bogensperger T, Schickhofer G (2006) Paper CIB-W18 39-12-4: a contribution to the design and system effect of cross-laminated timber (CLT). In: Proceedings of CIBW18 meeting thirty-nine, 28th-31th August 2006, Florence, Italy

Kreuzinger H (1999) Platten, Scheiben und Schalen: Ein Berechnungsmodell für gängige Statikprogramme. Bau Holz 101(1):3439

Larsson D (1997) Mechanical characterization of engineering materials by modal testing. PhD-Thesis. Chalmers University of Technology, Gothenburg, Sweden

Machek L, Militz H, Sierra-Alvarez R (2001) The use of an acoustic technique to assess wood decay in laboratory soil-bed tests. Wood Sci Technol 34(6):467-472

Maia NMM, Silva JMM (1997) Theoretical and experimental modal analysis. Research Studies Press, Taunton, Somerset

Reddy JN (1984) A simple higher-order theory for laminated composite plates. J Appl Mech 51(4):745-752

Ren JG (1986) A new theory of laminated plate. Compos Sci Technol 26(3):225-239

Steiger R, Gülzow A, Gsell D (2008) Non-destructive evaluation of elastic material properties of cross-laminated timber. In: Proceedings of COST E53 conference on "End user's needs for wood material and products". 29th-30th October 2008, The Netherlands, pp 171-182 